\title{
Management of primary hypothyroidism: statement by the British Thyroid Association Executive Committee
}

\author{
Onyebuchi Okosieme*, Jackie Gilbert†, Prakash Abraham‡, Kristien Boelaert§, Colin Dayanף, Mark Gurnell**,

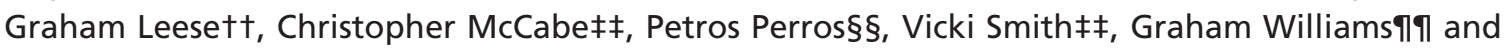 \\ Mark Vanderpump***
}

${ }^{*}$ Medicine, Prince Charles Hospital, Merthyr Tydfil, †Endocrinology, King’s College Hospital, London, $\ddagger$ Endocrinology, Aberdeen Royal Infirmary, Aberdeen, §Division of Medical Sciences, University of Birmingham, Birmingham, $\uparrow$ Centre for Endocrine and Diabetes Sciences, Cardiff University, Cardiff, ${ }^{* *}$ Endocrinology, Institute of Metabolic Science, Addenbrooke's Hospital, Cambridge, $\dagger \dagger$ Medical Research Institute, University of Dundee, Dundee, $+\$$ College of Medical and Dental Sciences, University of Birmingham, Birmingham, §§Endocrinology, Royal Victoria Infirmary, Newcastle, q $\uparrow$ Molecular Endocrinology Group, Department of Medicine, Imperial College London, London, and ${ }^{* *}$ Endocrinology, Royal Free London NHS Foundation Trust, London, UK

\section{Summary}

The management of primary hypothyroidism with levothyroxine (L-T4) is simple, effective and safe, and most patients report improved well-being on initiation of treatment. However, a proportion of individuals continue to suffer with symptoms despite achieving adequate biochemical correction. The management of such individuals has been the subject of controversy and of considerable public interest. The American Thyroid Association (ATA) and the European Thyroid Association (ETA) have recently published guidelines on the diagnosis and management of hypothyroidism. These guidelines have been based on extensive reviews of the medical literature and include sections on the role of combination therapy with L-T4 and liothyronine (L-T3) in individuals who are persistently dissatisfied with L-T4 therapy. This position statement by the British Thyroid Association (BTA) summarises the key points in these guidelines and makes recommendations on the management of primary hypothyroidism based on the current literature, review of the published positions of the ETA and ATA, and in line with best principles of good medical practice. The statement is endorsed by the Association of Clinical Biochemistry, (ACB), British Thyroid Foundation, (BTF), Royal College of Physicians (RCP) and Society for Endocrinology (SFE).

(Received 30 April 2015; returned for revision 18 May 2015; accepted 18 May 2015)

Correspondence: Dr Mark Vanderpump, Department of Endocrinology, Royal Free London NHS Foundation Trust, Pond Street, London NW3 2QG, UK. Tel.: 0207472 6280; E-mail: mark.vanderpump@nhs.net

Endorsed by the Association for Clinical Biochemistry and Laboratory Medicine, British Thyroid Foundation, Royal College of Physicians and the Society for Endocrinology

\section{Background}

Primary hypothyroidism is an insidious condition with a significant morbidity and often subtle and nonspecific symptoms and clinical signs. ${ }^{1,2}$ The earliest biochemical abnormality is an increase in serum thyroid-stimulating hormone (thyrotrophin) (TSH) concentration associated with normal serum free thyroxine (T4) and triiodothyronine (T3) concentrations (subclinical hypothyroidism), followed by a decrease in serum free T4 concentration, at which stage, most patients have symptoms and benefit from treatment (overt hypothyroidism). ${ }^{1-3}$ In the UK, the prevalence of spontaneous hypothyroidism is between $1 \%$ and $2 \%$, and it is more common in older women and ten times more common in women than in men. ${ }^{4,5}$ The cause is either chronic autoimmune disease [atrophic autoimmune thyroiditis or goitrous autoimmune thyroiditis (Hashimoto's thyroiditis)] or destructive treatment for hyperthyroidism with either radioiodine or surgery which may account for up to one-third of cases of hypothyroidism in the community. ${ }^{6}$ Less frequent causes include surgery and radioiodine ablation for benign nodular thyroid disease and thyroid cancer, external beam irradiation of malignant tumours of the head and neck and drugs including lithium, amiodarone and interferon. ${ }^{1}$ Congenital hypothyroidism affects about one newborn in 3500-4000 births. $^{7}$

The term subclinical hypothyroidism describes the finding of a raised serum TSH but a normal free T4. ${ }^{3,8,9}$ It represents a compensated state in which increased TSH output is required to maintain normal circulating thyroid hormone levels. An elevated serum TSH is a sensitive indicator of some degree of thyroid failure, and there is a clear inverse relationship with free T4 levels. The term implies that patients should be asymptomatic, although symptoms are difficult to assess, especially in patients in whom thyroid function tests have been checked because of nonspecific complaints such as tiredness. Subclinical hypothyroidism is common in studies of healthy people in the community and is found 
in $5-10 \%$ of the population, being more common in women and increasing with age. ${ }^{9}$ It can progress to overt hypothyroidism, particularly if antithyroid antibody positive. ${ }^{10}$ In the community, the most common aetiology is chronic autoimmune thyroiditis. ${ }^{6}$

There has been a growing controversy about the upper limit of the reference range for serum TSH. ${ }^{11,12}$ Reference ranges are derived from a reference population that comprises a large group of subjects who do not have thyroid disease and are otherwise well. By convention, a reference range usually only comprises $95 \%$ of a reference population. Thus, $2.5 \%$ of 'normal' individuals will fall above the reference range and $2.5 \%$ will fall below the range. For serum TSH, the reference population shows a log normal distribution and has a diurnal variation with the reference range in thyroid disease free individuals typically cited as between 0.4 and $4.0 \mathrm{mU} /{ }^{8}{ }^{8}$ The reference range varies in different ethnic communities, pregnancy and by age. ${ }^{13}$ It has been reported that serum TSH distribution progressively shifts towards higher concentration with age. ${ }^{13}$ Studies addressing the relationship between symptoms suggestive of thyroid hormone deficiency and the biochemical finding of subclinical hypothyroidism have produced conflicting results. ${ }^{3}$ It is recognized that up to one-quarter of the healthy normal population may have 'hypothyroid' symptoms such as lethargy and weight gain. ${ }^{14}$ The evidence for benefit in randomized controlled trials of thyroid hormone treatment in subclinical hypothyroidism is inconsistent and further studies are needed., ${ }^{3,15}$ Although epidemiological studies have shown an association between subclinical hypothyroidism and coronary heart disease in younger people $(<65 \text { years })^{16}$ or those with high TSH $(>10 \mathrm{mU} / \mathrm{l}),{ }^{17}$ recent evidence suggests that in older people, higher serum TSH and lower free $\mathrm{T} 4$ concentrations within the euthyroid range are associated with lower risk of multiple adverse events including mortality. ${ }^{18}$ In neonates and children, pregnancy, or in women trying to conceive, a mildly increased serum TSH should always be treated as mild thyroid failure which is associated with adverse outcomes for both mother and foetus. ${ }^{19}$

In England, 3\% of people are prescribed synthetic L-T4 ${ }^{20}$ with the goal of therapy being to restore patient well-being and normalize serum TSH levels. ${ }^{21}$ Most patients respond satisfactorily, but a minority of treated individuals experience persistent symptoms despite adequate biochemical correction. ${ }^{22}$ The care of such individuals is challenging and remains the subject of considerable public interest. ${ }^{23}$ Although some nonmainstream practitioners advocate the use of alternative thyroid therapies including liothyronine (L-T3) and thyroid extracts, combination therapy with L-T4 and L-T3 is also prescribed by accredited specialists. In the United States, $3 \cdot 6 \%$ of endocrinologists report that they would give L-T3 to patients with hypothyroidism with persistent symptoms and normal biochemical thyroid status. ${ }^{24}$

In 2008, the Royal College of Physicians (RCP) issued a position statement on the diagnosis and management of primary hypothyroidism endorsed by various professional bodies, namely the British Thyroid Association (BTA), the British Thyroid Foundation (BTF), the Association for Clinical Biochemistry and Laboratory Medicine (ACB), the British Society of Paediatric Endocrinology and Diabetes (BSPED), the Society for Endocrinology (SFE) and the Royal College of General Practitioners (RCGP). ${ }^{25}$ This RCP statement, updated in 2011, did not support the use of thyroid extracts or L-T3 in the treatment of hypothyroidism and recommended that L-T3 'should be reserved for use by accredited endocrinologists in individual patients'. ${ }^{25}$

More recently, the European Thyroid Association (ETA) published guidelines on the use of L-T4/L-T3 combination therapy in primary hypothyroidism ${ }^{26}$ and subsequently, the American Thyroid Association (ATA) ${ }^{27}$ and the Latin America Thyroid Society (LATS) ${ }^{28}$ have released their own separate hypothyroidism treatment guidelines. These international guidelines have generated further interest in the role of L-T3 in hypothyroidism and have been interpreted in some quarters as representing a departure from the earlier UK RCP position. ${ }^{29}$

It is recognized that clinicians must be committed to delivering individualized patient-centred care and shared decision-making in all patients with primary hypothyroidism. This report summarizes the key points in the ETA and ATA guidelines and contains a statement on the management of primary hypothyroidism written by the BTA and endorsed by the ACB, BTF, RCP and SFE based on the current evidence and international guidelines.

\section{Methods}

The current statement serves to update the previous 2008 and 2011 RCP joint position statements on the diagnosis and management of primary hypothyroidism. We have focused on patients with primary hypothyroidism and have not addressed in detail the care of subgroups such as pregnant women, patients treated for thyroid cancer or secondary hypothyroidism. Excellent guidelines for the management of these other conditions are available elsewhere. The statement is intended to provide concise guidance for primary care practitioners, hospital physicians, clinical biochemists and endocrinologists involved in caring for patients with hypothyroidism. A plain English summary of the guidelines will be made available for patients and interested members of the public on the websites of the BTA and BTF.

The statement has been developed following consultation within the BTA and with relevant stakeholder groups. All authors are members of the BTA executive committee with expertise in thyroid disease management and research. An initial face-to-face meeting was held in December 2014 by committee members, during which the scope and remit of the proposed position statement was decided. Following this, individual reviewers undertook a primary review that addressed key clinical questions relating to the diagnosis, indications, monitoring, therapeutic choice and treatment targets in the management of hypothyroidism. The primary reviewers examined the recent hypothyroidism guidelines of the ATA and ETA including original research informing these guidelines that were considered relevant to the remit of the current position statement. Furthermore, a systematic search of PubMed was undertaken, and additional references were sourced through references of 
individual articles. An initial draft was sent out to consultation by email to executive and senior members of the BTA who revised the original draft. Consensus on recommendations was reached through discussions. Wider consultations were then held with representatives of the SFE, ACB and RCP, as well as with the BTF, the patient support charity for thyroid disorders. The document was finalized following feedback from each of these bodies, and agreement from all authors was reached on the final statement. No external funding was received, either by the BTA or by individual members, for the development of this statement, and all conflict of interests are declared.

In addition to the statement, we have summarized the relevant recommendations from the ATA and ETA guidelines relating to the diagnosis and management of primary hypothyroidism. These recommendations are grouped into themes each addressing a specific clinical question. The strength of the recommendations and the quality of the evidence supporting these recommendations are included as judged by the authors of the original guidelines. Recommendations made in the BTA statement are also rated as strong (1) or weak recommendations (2) and the quality of evidence rated as high $(+++)$, moderate $(++0)$, low $(+00)$ or insufficient $(000)$ according to the GRADE system classification for clinical practice recommendations. $^{30,31}$

\section{Summary of ETA and ATA guidelines}

The key recommendations are summarized in Tables 1-10, and each Table addresses a relevant question reviewed in either or both guidelines.
- L-T4 is the treatment of choice in hypothyroidism. The goal of therapy is to restore physical and psychological wellbeing and normalize serum TSH (Table 1).

- The adequacy of therapy should be determined both by clinical and biochemical assessment, and undertreatment and overtreatment should be avoided due to their detrimental health effects (Table 2).

- There is insufficient evidence to recommend monitoring serum T3 as a therapeutic target in hypothyroidism (Table 3).

- A proportion of patients on L-T4 therapy have persistent symptoms despite normal serum TSH levels. Such symptoms should be acknowledged and alternative aetiologies sought (Table 4).

- There is insufficient evidence that combination therapy with L-T4 and L-T3 therapy is superior to L-T4 monotherapy (Table 5).

- L-T4/L-T3 therapy may be considered as an 'experimental approach' in compliant L-T4-treated hypothyroid patients who have persistent complaints despite reference range serum TSH values, provided they have received adequate chronic disease support and associated autoimmune diseases have been ruled out (ETA) (Table 5-6). There is currently insufficient evidence to support the routine use of such a trial of L-T4 and L-T3 outside a 'formal clinical trial or $\mathrm{N}$ of 1 trial' (ATA) (Table 5).

- Thyroid hormone therapy is not recommended in euthyroid individuals with (i) suggestive symptoms of hypothyroidism, (ii) obesity, (iii) depression or (iv) urticaria (Table 7).

- The routine use of thyroid extracts, L-T3 monotherapy, compounded thyroid hormones, iodine containing preparations, dietary supplementation, nutraceuticals and over the counter

Table 1. Choice of therapy and therapeutic targets

\begin{tabular}{|c|c|c|c|}
\hline Question & Guideline & Recommendation & $\begin{array}{l}\text { Strength } \\
\text { Evidence }\end{array}$ \\
\hline $\begin{array}{l}\text { Are clinical parameters such as cold sensitivity } \\
\text { and dry skin useful by themselves for } \\
\text { assessing adequacy of L-T4 replacement in } \\
\text { primary hypothyroidism? }\end{array}$ & ATA & $\begin{array}{l}\text { Although it may be helpful to follow changes in clinical symptoms } \\
\text { longitudinally in patients treated for hypothyroidism, symptoms } \\
\text { alone lack sensitivity and specificity and therefore are not } \\
\text { recommended for judging adequacy of replacement in the absence } \\
\text { of biochemical assessment. Therefore, symptoms should be } \\
\text { followed, but considered in the context of serum TSH values, } \\
\text { relevant comorbidities and other potential causes }\end{array}$ & $1 /+00$ \\
\hline $\begin{array}{l}\text { Are tissue markers of thyroid hormone action } \\
\text { helpful in determining the adequacy of L-T4 } \\
\text { replacement in primary hypothyroidism? }\end{array}$ & ATA & $\begin{array}{l}\text { Tissue biomarkers of thyroid hormone action are not recommended } \\
\text { for routine clinical use, outside of the research setting, as these } \\
\text { parameters are not sensitive, specific, readily available or } \\
\text { standardized }\end{array}$ & $2 /+00$ \\
\hline
\end{tabular}


Table 2. Effects of inadequate or excess L-T4 Therapy

\begin{tabular}{|c|c|c|c|}
\hline $\begin{array}{l}\text { What are the potential deleterious } \\
\text { effects of excessive L-T4? }\end{array}$ & ATA & $\begin{array}{l}\text { The deleterious health effects of iatrogenic thyrotoxicosis include } \\
\text { atrial fibrillation and osteoporosis. Because of these effects, we } \\
\text { recommend avoiding thyroid hormone excess and subnormal } \\
\text { serum TSH values, particularly serum TSH values below } 0 \cdot 1 \mathrm{mU} / \mathrm{L} \text {, } \\
\text { especially in older persons and postmenopausal women }\end{array}$ & $1 /++0$ \\
\hline
\end{tabular}

Table 3. Role of serum free T3 in the management of hypothyroidism

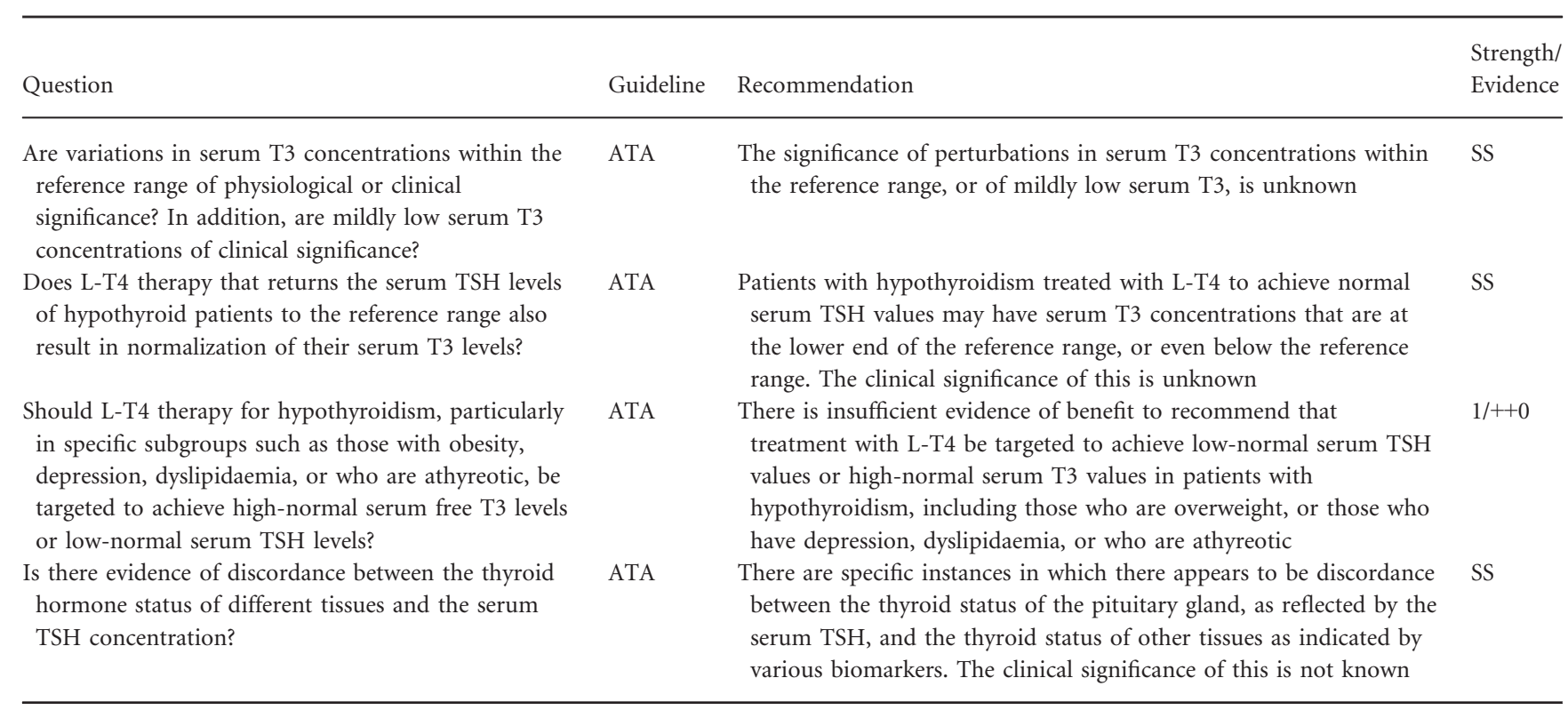

SS, Summary statement where formal clinical recommendation is not feasible because of sparse evidence.

preparations are not recommended in the management of hypothyroidism (Table 8).

- Genetic characterization for deiodinase gene polymorphisms is not recommended as a guide to the use of combination L-T3 and L-T4 therapy in hypothyroidism (Table 9).

- Clinicians treating patients with hypothyroidism have an ethical obligation to avoid potential harmful therapies without proven benefits. The balance of clinical evidence regarding the efficacy of monotherapy $v s$ combination therapy calls for further well-designed randomized controlled trials (Table 10).

\section{Commentary}

The ETA and ATA guidelines differ in scope although the key recommendations on the diagnosis and management of hypothyroidism are comparable. The ATA guidelines comprehen- sively address the management of hypothyroidism and include sections on inhospital management, secondary hypothyroidism, the use of thyroid hormone analogues, and ethical considerations for clinicians and researchers. The ETA document on the other hand focuses specifically on the use of combination therapy and includes carefully considered suggestions for prescribing L-T3 in practice.

Both guidelines strongly recommend that L-T4 remains the therapy of choice in hypothyroidism and do not support the routine use of L-T4/L-T3 combination therapy due to insufficient evidence from controlled trials, lack of long-term L-T3 safety data, and unavailability of L-T3 formulations that mirror natural physiology.

A key feature of both guidelines is the acknowledgement of the subset of L-T4-treated patients who suffer persistent symptoms despite adequate biochemical thyroid status. However, while both guidelines agree that a trial of L-T3 may 
Table 4. Patient satisfaction with L-T4 therapy

\begin{tabular}{|c|c|c|c|}
\hline & & $\begin{array}{l}\text { Data suggest that } 5-10 \% \text { of L-T4-treated hypothyroid patients with } \\
\text { normal serum TSH have persistent symptoms which can be related to } \\
\text { the disease and L-T4 therapy }\end{array}$ & $2 /+00$ \\
\hline $\begin{array}{l}\text { Is there a biological rationale for persistent } \\
\text { complaints in L-T4-treated hypothyroid } \\
\text { patients? }\end{array}$ & ETA & $\begin{array}{l}\text { Suggested explanations for persistent symptoms in L-T4-treated } \\
\text { hypothyroid patients despite normalization of serum TSH, include } \\
\text { awareness of a chronic disease, presence of associated autoimmune } \\
\text { diseases, thyroid autoimmunity per se (independent of thyroid } \\
\text { function), and inadequacy of L-T4 treatment to restore physiological } \\
\text { T4 and T3 concentrations in serum and tissues }\end{array}$ & $2 /+00$ \\
\hline $\begin{array}{l}\text { What tools may be useful in the clinical or } \\
\text { research setting, to measure the impact of L- } \\
\text { T4 replacement for primary hypothyroidism } \\
\text { on patients' physical or psychological well- } \\
\text { being, treatment satisfaction, or treatment } \\
\text { preferences? }\end{array}$ & ATA & $\begin{array}{l}\text { Of the established instruments used to measure hypothyroid symptoms, } \\
\text { data are lacking regarding their sensitivity and specificity in the } \\
\text { 'everyday' clinical setting to recommend their routine clinical use. } \\
\text { Further studies are needed to determine whether and how to combine } \\
\text { general psychological screening instruments, hypothyroidism-specific } \\
\text { tools, and laboratory assessment of thyroid function to measure the } \\
\text { impact of L-T4 replacement therapy on psychological well-being, } \\
\text { treatment satisfaction and preference in clinical practice. } \\
\text { A combination of general instruments, combined with } \\
\text { hypothyroidism-specific tools, may be the most effective way to } \\
\text { examine psychological well-being in the L-T4-treated population in the } \\
\text { research setting }\end{array}$ & $1 /++0$ \\
\hline
\end{tabular}

occasionally be indicated in such patients, there are significant differences between the guidelines in the implementation of such a trial.

The ETA would consider a carefully monitored experimental trial of L-T3 if symptoms persist after comorbid conditions have been excluded. Such a trial should be conducted under specialist supervision, be reassessed after a period of 3 months and preferably include objective evaluations of response with standardized quality of life tools.

The ATA goes further by insisting that any such trial must be rigorously implemented, either as part of a clinical trial or $\mathrm{N}$ of 1 trial, with formal ethical and governance approvals. In addition, the ATA highlights the ethical and legal obligations inherent on clinicians managing hypothyroidism including the responsibility to avoid potentially harmful therapies without proven advantage over existing therapies. The authors further assert that the balance of clinical evidence on the benefits of combination therapy over L-T4 monotherapy would demand that further randomized controlled trials are indicated.

The 2011 RCP statement concluded that L-T3 'should be reserved for use by accredited endocrinologists in individual patients' but did not specifically address management strategies for L-T4-treated patients with persistent symptoms after nonthyroid causes are excluded. Thus, the current ETA and ATA guidelines can be seen as an addition rather than a departure from this position.

\section{Statement}

Based on the current literature and following review of the published positions of the ETA and ATA, and in line with the best principles of good medical practice, the BTA, ACB, BTF, RCP and SFE have agreed the following statement:

1 It is important that high-quality, unbiased, evidence-based information about hypothyroidism is made available to patients and the public. We recognize the need to engage with patients and promote more research in hypothyroidism.

2 The diagnosis of primary hypothyroidism is based on clinical features of hypothyroidism supported by biochemical evidence that is elevated serum TSH together with low free T4 (overt hypothyroidism) or normal free T4 (subclinical hypothyroidism). Primary hypothyroidism should not be diagnosed in individuals with normal serum TSH who otherwise have intact pituitary function $(1 /++0)$. 
Table 5. Combination therapy with L-T4 and L-T3

\begin{tabular}{|c|c|c|c|}
\hline Question & Guideline & Recommendation & $\begin{array}{l}\text { Strength/ } \\
\text { Evidence }\end{array}$ \\
\hline \multirow{3}{*}{$\begin{array}{l}\text { Is combination therapy with } \mathrm{L}-\mathrm{T} 4 \text { and } \mathrm{L}-\mathrm{T} 3 \\
\text { superior to } \mathrm{L}-\mathrm{T} 4 \text { monotherapy in the } \\
\text { management of hypothyroidism? }\end{array}$} & ETA & $\begin{array}{l}\text { Insufficient evidence that } \mathrm{L}-\mathrm{T} 4+\mathrm{L}-\mathrm{T} 3 \text { combination therapy is superior } \\
\text { to L-T4 monotherapy }\end{array}$ & $1 /++0$ \\
\hline & & L-T4 monotherapy remains the standard treatment of hypothyroidism & $1 /+++$ \\
\hline & ATA & $\begin{array}{l}\text { There is no consistently strong evidence of superiority of combination } \\
\text { therapy over monotherapy with L-T4. Therefore, we recommend } \\
\text { against the routine use of combination treatment with L-T4 and L-T3 } \\
\text { as a form of thyroid replacement therapy in patients with primary } \\
\text { hypothyroidism, based on conflicting results of benefits from } \\
\text { randomized controlled trials comparing this therapy to L-T4 therapy } \\
\text { alone and a paucity of long-term outcome data }\end{array}$ & $2 /++0$ \\
\hline \multirow[t]{4}{*}{$\begin{array}{l}\text { Is there a place for combination therapy with } \\
\mathrm{L}-\mathrm{T} 4 \text { and L-T3 in patients who have } \\
\text { persistent symptoms despite serum TSH } \\
\text { values within the reference range? }\end{array}$} & ETA & $\begin{array}{l}\text { Consider L-T4 and L-T3 as an experimental approach in compliant L- } \\
\text { T4-treated hypothyroid patients who have persistent complaints despite } \\
\text { serum TSH values within the reference range, provided they have } \\
\text { previously been given support to deal with the chronic nature of their } \\
\text { disease and associated autoimmune diseases have been ruled out }\end{array}$ & $2 /+00$ \\
\hline & & $\begin{array}{l}\text { L-T4 and L-T3 are not recommended in pregnancy and in patients with } \\
\text { cardiac arrhythmias }\end{array}$ & $2 /+00$ \\
\hline & & Discontinue L-T4 and L-T3 if no improvement after 3 months & $2 /++0$ \\
\hline & ATA & $\begin{array}{l}\text { For patients with primary hypothyroidism who feel unwell on L-T4 } \\
\text { therapy alone (in the absence of an allergy to L-T4 constituents or an } \\
\text { abnormal serum TSH), there is currently insufficient evidence to } \\
\text { support the routine use of a trial of a combination of L-T4 and L-T3 } \\
\text { therapy outside a formal clinical trial or N of } 1 \text { trial, due to } \\
\text { uncertainty in long-term risk benefit ratio of the treatment and } \\
\text { uncertainty as to the optimal definition of a successful trial to guide } \\
\text { clinical decision-making }\end{array}$ & 000 \\
\hline
\end{tabular}

Table 6. Dose, administration and monitoring of L-T3 therapy

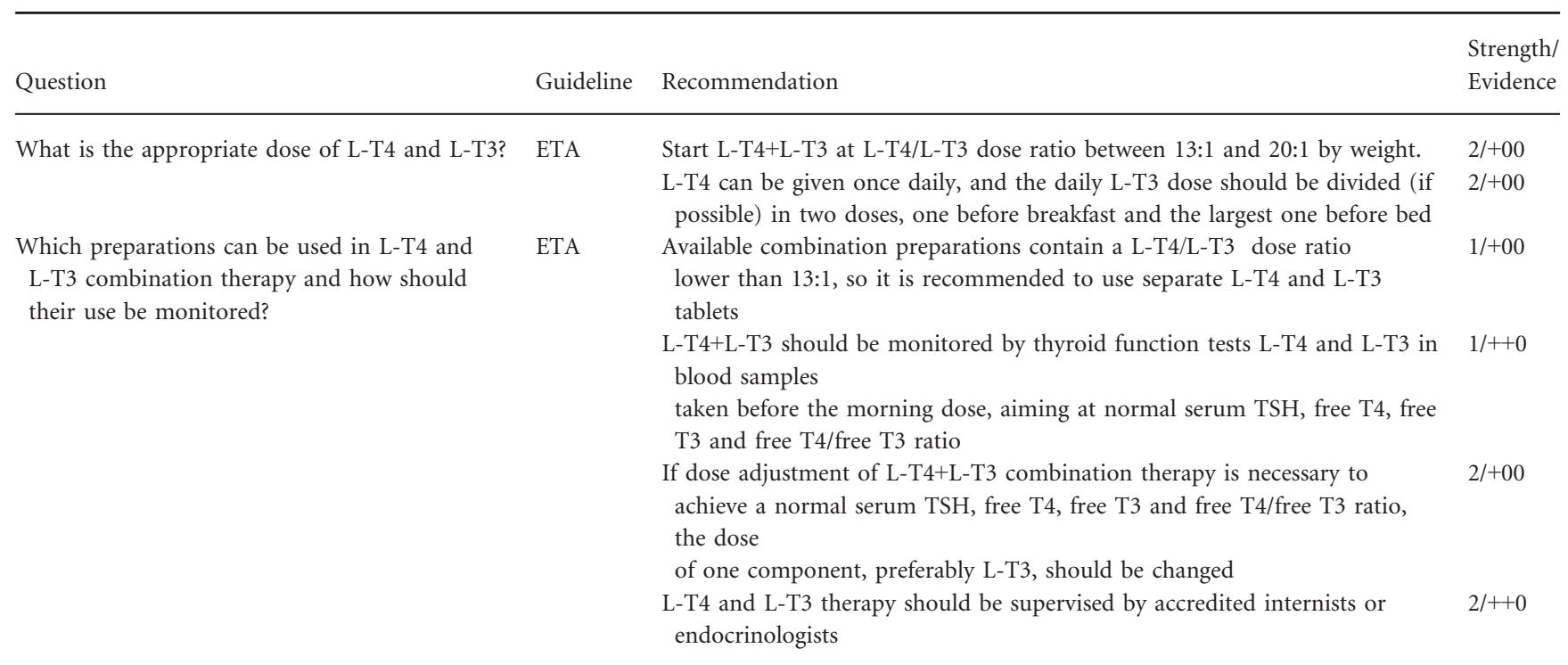

3 The evidence in favour of narrowing the serum TSH reference range is not convincing and cannot justify the large increase in the number of healthy people that would require investigation $(1 /++0)$.

4 A significant proportion of healthy subjects in the community have asymptomatic chronic autoimmune thyroiditis and a significant proportion have subclinical hypothyroidism. Spontaneous recovery has been described in subjects with subclinical hypothyroidism. It is more likely in those with negative antithyroid antibodies and serum TSH levels less than $10 \mathrm{mU} / \mathrm{l}$, and within the first 2 years after diagnosis. The higher the serum TSH value, the greater the likelihood of development of overt 
Table 7. Use of thyroid hormone therapy in euthyroid individuals

\begin{tabular}{|c|c|c|c|}
\hline Question & Guideline & Recommendation & $\begin{array}{l}\text { Strength/ } \\
\text { Evidence }\end{array}$ \\
\hline $\begin{array}{l}\text { Is there a role for the use of L-T4 to treat } \\
\text { biochemically euthyroid patients with } \\
\text { symptoms that overlap with those of } \\
\text { hypothyroidism? }\end{array}$ & ATA & $\begin{array}{l}\text { Strongly recommend against the use of L-T4 treatment in patients who } \\
\text { have nonspecific symptoms and normal biochemical indices of thyroid } \\
\text { function, as no role exists for use of L-T4 in this situation }\end{array}$ & $1 /+++$ \\
\hline \multirow[t]{2}{*}{$\begin{array}{l}\text { Is there a role for the use of } \mathrm{L}-\mathrm{T} 4 \text { or } \mathrm{L}-\mathrm{T} 3 \\
\text { to treat euthyroid patients with } \\
\text { depression? }\end{array}$} & ATA & $\begin{array}{l}\text { Recommend against the routine use of L-T4 for the treatment of } \\
\text { euthyroid individuals with depression, due to a paucity of controlled } \\
\text { data examining treatment efficacy in this setting }\end{array}$ & $2 /+00$ \\
\hline & & $\begin{array}{l}\text { Although some uncontrolled and nonrandomized data exist concerning } \\
\text { successful use of L-T3 in euthyroid patients with depression, larger, } \\
\text { prospective randomized placebo controlled studies are needed to more } \\
\text { completely define the potential role of L-T3 in this condition, } \\
\text { balancing the risks and benefits of therapy to measurable clinical } \\
\text { outcomes }\end{array}$ & $2 /+00$ \\
\hline \multirow[t]{2}{*}{$\begin{array}{l}\text { Is there a role for the use of } \mathrm{L}-\mathrm{T} 4 \text { or } \mathrm{L}-\mathrm{T} 3 \\
\text { to treat euthyroid patients with obesity? }\end{array}$} & ATA & $\begin{array}{l}\text { Recommend against the treatment of obesity with L-T4 in euthyroid } \\
\text { individuals, due to a lack of treatment efficacy for this condition }\end{array}$ & $1 /++0$ \\
\hline & & $\begin{array}{l}\text { Recommend against the treatment of obesity with synthetic L-T3 due to } \\
\text { a lack of controlled data proving treatment efficacy for this indication }\end{array}$ & $1 /+00$ \\
\hline $\begin{array}{l}\text { Is there a role for the use of } \mathrm{L}-\mathrm{T} 4 \text { to treat } \\
\text { euthyroid patients with urticaria? }\end{array}$ & ATA & $\begin{array}{l}\text { Recommend against the treatment of urticaria with L-T4 in euthyroid } \\
\text { individuals, due to a lack of treatment efficacy for this condition }\end{array}$ & $1 /++0$ \\
\hline
\end{tabular}

Table 8. Role of other therapies in hypothyroidism

\begin{tabular}{|c|c|c|c|}
\hline Question & Guideline & Recommendation & $\begin{array}{l}\text { Strength/ } \\
\text { Evidence }\end{array}$ \\
\hline $\begin{array}{l}\text { Is treatment with thyroid extracts superior } \\
\text { to treatment with L-T4 alone? }\end{array}$ & ATA & $\begin{array}{l}\text { Although there is preliminary evidence from a short-duration study that } \\
\text { some patients may prefer treatment with extracts, high-quality } \\
\text { controlled long-term outcome data are lacking to document superiority } \\
\text { of this treatment compared to L-T4 therapy. Furthermore, there are } \\
\text { potential safety concerns related to the use of thyroid extracts, such as } \\
\text { the presence of supraphysiological serum T3 levels and a paucity of } \\
\text { long-term safety outcome data }\end{array}$ & $1 /++0$ \\
\hline $\begin{array}{l}\text { Are there data regarding therapy with L-T3 } \\
\text { alone, either as standard L-T3 or as } \\
\text { sustained release L-T3, that support the } \\
\text { use of L-T3 therapy alone for the } \\
\text { treatment of hypothyroidism? }\end{array}$ & ATA & $\begin{array}{l}\text { Although short-term outcome data in hypothyroid patients suggest that } \\
\text { thrice daily synthetic L-T3 may be associated with beneficial effects on } \\
\text { parameters such as weight and lipids, longer term controlled clinical } \\
\text { trials using a longer acting form of L-T3 are needed, before considering } \\
\text { the endorsement of synthetic L-T3 therapy for routine clinical use }\end{array}$ & $1 /++0$ \\
\hline $\begin{array}{l}\text { What is the recommendation regarding } \\
\text { therapy with compounded thyroid } \\
\text { hormones (either L-T4 or L-T3) for } \\
\text { treatment of hypothyroidism based on } \\
\text { current evidence? }\end{array}$ & ATA & $\begin{array}{l}\text { Recommend against the routine use of compounded thyroid hormones } \\
\text { due to concerns about safety and potency and due to the lack of data } \\
\text { proving superiority to standard thyroid hormone preparations. } \\
\text { However, in the case of suspected allergy to an excipient of standard } \\
\text { thyroid hormone preparations that cannot be avoided with a change in } \\
\text { brand or dose formulation, including a trial of L-T4 gel capsules, it } \\
\text { may be reasonable to consider use of compounded products, although } \\
\text { a controlled study of this approach has not been published }\end{array}$ & $1 /+00$ \\
\hline $\begin{array}{l}\text { Is there a role for the use of dietary } \\
\text { supplementation, nutraceuticals and over } \\
\text { the counter products in either } \\
\text { hypothyroid or euthyroid individuals? }\end{array}$ & ATA & $\begin{array}{l}\text { Recommend against the use of dietary supplements, nutraceuticals or } \\
\text { other over the counter products either in euthyroid individuals or as a } \\
\text { means of treating hypothyroidism. Particularly caution against the use } \\
\text { of pharmacologic doses of iodine because of the risk of thyrotoxicosis } \\
\text { and hypothyroidism in those with intact thyroid glands susceptible to } \\
\text { becoming further dysregulated because of underlying thyroid pathology }\end{array}$ & $1 /+00$ \\
\hline
\end{tabular}

hypothyroidism in subjects with chronic autoimmune thyroiditis.

5 Synthetic L-T4 remains the treatment of choice in hypothyroidism with the aim of therapy being to restore physical and psychological well-being while maintaining normal laboratory reference range serum TSH levels $(1 /++0)$. After initiation of therapy, TSH should be monitored 6-8 weekly and the dose of L-T4 should be adjusted until a stable TSH is achieved, after 
Table 9. Impact of genetic polymorphisms on the response to therapy

\begin{tabular}{|c|c|c|c|}
\hline Question & Guideline & Recommendation & $\begin{array}{l}\text { Strength/ } \\
\text { Evidence }\end{array}$ \\
\hline $\begin{array}{l}\text { Could it be that trials comparing L-T4 and L-T3 } \\
\text { combination therapy and L-T4 monotherapy have } \\
\text { not targeted the right population? }\end{array}$ & ETA & $\begin{array}{l}\text { Limited data suggest that psychological well-being and preference for } \\
\text { L-T4 and L-T3 combination therapy may be influenced by } \\
\text { polymorphisms in thyroid hormone pathway genes, specifically in } \\
\text { thyroid hormone transporters and deiodinases }\end{array}$ & $2 /+00$ \\
\hline $\begin{array}{l}\text { Should genetic characterization according to type } 2 \\
\text { deiodinase gene polymorphism status be used to } \\
\text { guide the use of combination synthetic L-T3 and L- } \\
\text { T4 therapy in hypothyroidism, in order to optimize } \\
\text { biochemical and clinical outcomes? }\end{array}$ & ATA & $\begin{array}{l}\text { Currently, genetic testing is not recommended as a guide to selecting } \\
\text { therapy for } 3 \text { reasons. (i) Although there are data suggesting that } \\
\text { specific polymorphisms of the type } 2 \text { deiodinase gene might be } \\
\text { associated with therapeutic response to combination synthetic L-T3 } \\
\text { and L-T4 therapy, controlled confirmatory studies are needed. } \\
\text { (ii) Currently, genetic testing for these specific deiodinase } \\
\text { polymorphisms is only available in the research setting. (iii) The } \\
\text { small effect of the type } 2 \text { deiodinase gene variants identified so far } \\
\text { that do affect thyroid hormone concentrations suggests that other } \\
\text { factors (e.g. yet unidentified genetic variants) may play a far greater } \\
\text { role in determining an individual patient's thyroid hormone } \\
\text { concentrations }\end{array}$ & $1 /++0$ \\
\hline
\end{tabular}

Table 10. Ethical considerations

\begin{tabular}{lll}
\hline Question & Guideline & Recommendation \\
\hline $\begin{array}{l}\text { What are the ethical obligations of } \\
\text { clinicians in treating hypothyroidism? }\end{array}$ & ATA & $\begin{array}{l}\text { Clinical ethical principles in L-T4 treatment for hypothyroidism } \\
\text { revolve around two core ethical principles in medicine: the } \\
\text { principles of beneficence and nonmaleficence, which guide the risk/ } \\
\text { benefit analysis in clinical practice, and protect clinicians from } \\
\text { deviating from practice to satisfy inappropriate patient demands. } \\
\text { Additional ethical obligations revolve around the professional }\end{array}$ \\
$\begin{array}{l}\text { What are the research ethics issues } \\
\text { involved in evaluating or designing } \\
\text { clinical trials for the treatment of } \\
\text { hypothyroidism? }\end{array}$ & $\begin{array}{l}\text { There should be recognition that there are not enough data to } \\
\text { resolve clinical disagreement amongst thyroid experts (called } \\
\text { 'clinical equipoise') regarding treatment for hypothyroidism. } \\
\text { Clinical equipoise is disturbed only by the results of well-designed } \\
\text { randomized controlled trials that have the statistical power to settle } \\
\text { the question of efficacy between monotherapy and combination } \\
\text { therapy, or other forms of therapy }\end{array}$ \\
&
\end{tabular}

which TSH can be checked 4-6 monthly, and then annually (1/ $+00)$.

6 It is acknowledged that a proportion of individuals on L-T4 are not satisfied with therapy and have persistent symptoms despite a normal serum TSH. Such symptoms should be given due consideration and patients should be thoroughly evaluated for other potentially modifiable conditions (Box 1). In some cases, a retrospective review of the original diagnosis of hypothyroidism may be necessary. Symptom and lifestyle management support should be provided and further dose adjustments may be required $(1 /+00)$.

7 Although fine tuning of serum TSH levels within the reference range may be indicated for individual patients, deliberate serum TSH suppression with high dose thyroid hormone replacement therapy (serum TSH $<0.1 \mathrm{mU} / \mathrm{L}$ ) should be avoided where possible as this carries a risk of adverse effects such as cardiac rhythm disorders including atrial fibrillation, strokes, osteoporosis and fracture $(1 /++0)$. As an exception, patients with a history of thyroid cancer may require deliberate suppression of serum TSH if there is a significant risk of recurrence.

8 For the vast majority of patients on L-T4, brand or named supplier prescribing is not considered necessary $(2 /+00)$. The Medicines and Healthcare Products Regulatory Agency (MHRA) have recently made recommendations to ensure the quality and consistency of L-T4 tablets that are on the UK market. Rarely, patients may require a specific brand of L-T4 to be prescribed due to intolerance of generic preparations. 
Box 1. Some possible causes of persistent symptoms in euthyroid patients on L-T4

\begin{tabular}{|lcc}
\hline Endocrine/autoimmune & Nutritional & Lifestyle \\
Diabetes mellitus & Vitamin B12 deficiency & Stressful life events \\
Adrenal insufficiency & Folate deficiency & Poor sleep pattern \\
Hypopituitarism & Vitamin D deficiency & Work-related exhaustion \\
Coeliac disease & Iron deficiency & Alcohol excess \\
Pernicious anaemia & Metabolic & Others \\
Haematological & Obesity & Obstructive sleep apnoea \\
Anaemia & Hypercalcaemia & Viral and postviral syndromes \\
Multiple myeloma & Electrolyte imbalance & Chronic fatigue syndrome \\
End-organ damage & Drugs & Carbon monoxide poisoning \\
Chronic kidney disease & Beta-blockers & Depression and anxiety \\
Chronic liver disease & Statins & Polymyalgia rheumatica \\
Congestive cardiac failure & Opiates & Fibromyalgia \\
\hline
\end{tabular}

9 Serum T3 should not be used as a therapeutic target in the management of hypothyroidism as the value of this approach is unproven $(1 /+00)$.

$10 \mathrm{~L}-\mathrm{T} 4 / \mathrm{L}-\mathrm{T} 3$ combination therapy in patients with hypothyroidism should not be used routinely, as there is insufficient evidence to show that combination therapy is superior to L-T4 monotherapy $(1 /++0)$.

11 Clinicians have an ethical responsibility to adhere to the highest professional standards of good medical practice rooted in sound evidence. This includes not prescribing potentially harmful therapies without proven advantages over existing treatments.

12 If a decision is made to embark on a trial of L-T4/L-T3 combination therapy in patients who have unambiguously not benefited from L-T4, then this should be reached following an open and balanced discussion of the uncertain benefits, likely risks of over-replacement and lack of long-term safety data. Such patients should be supervised by accredited endocrinologists with documentation of agreement after fully informed and understood discussion of the risks and potential adverse consequences. Many clinicians may not agree that a trial of L-T4/LT3 combination therapy is warranted in these circumstances and their clinical judgement must be recognized as being valid given the current understanding of the science and evidence of the treatments $(2 /+00)$.

13 The serum TSH reference range in pregnancy is $0.4-2.5 \mathrm{mU} /$ 1 in the first trimester and $0.4-3.0 \mathrm{mU} / 1$ in the second and third trimesters or should be based on the trimester-specific reference range for the population if available. These reference ranges should be achieved where possible with appropriate doses of L-T4 preconception and most importantly in the first trimester $(1 /++0)$. L-T4/L-T3 combination therapy is not recommended in pregnancy $(1 /+00)$.

14 There is no convincing evidence to support routine use of thyroid extracts, L-T3 monotherapy, compounded thyroid hormones, iodine containing preparations, dietary supplementation and over the counter preparations in the management of hypothyroidism $(1 /+00)$.

\section{Conclusions}

This updated position statement reflects current best practice in the management of primary hypothyroidism. Levothyroxine therapy offers a safe, rational and simplified approach to the correction of hypothyroidism, and for the vast majority of patients, treatment results in improved physical and psychological well-being. However, the management of patients with a suboptimal clinical response remains challenging. The benefits of combination therapy with L-T4 and L-T3 are still unproven, and the potential for harm exists with unregulated use of unapproved therapies. Thus, future RCTs will be of value, especially on the use of combination therapy in patients with specified genetic or clinical characteristics. Strategies to improve medication adherence, optimize drug delivery and standardize thyroid hormone formulations will ultimately improve patient outcomes. The BTA hopes that this position statement along with other recently published scientific guidelines would support clinicians in implementing evidence-based strategies in the management of hypothyroidism.

\section{Acknowledgements}

Comments on the manuscript were kindly received from $\mathrm{Dr}$ WMG Tunbridge, Professor AP Weetman, Professor J Lazarus, Association for Clinical Biochemistry and Laboratory Medicine, Joint Specialty Committee for Diabetes and Endocrinology of the Royal College of Physicians, Clinical Committee of the Society for Endocrinology, and Trustees of the British Thyroid Foundation.

\section{References}

1 Roberts, C.G. \& Ladenson, P.W. (2004) Hypothyroidism. Lancet, 363, 793-803.

2 Vaidya, B. \& Pearce, S.H. (2008) Management of hypothyroidism in adults. BMJ, 337, 284-289.

3 Cooper, D.S. \& Biondi, B. (2012) Subclinical thyroid disease. Lancet, 379, 1142-1154. 
4 Clinical Knowledge Summaries. Hypothyroidism. National Institute for Health and Clinical Excellence (2011). Available from: http://cks.nhs.uk/hypothyroidism/management. (Accessed: 17 May 2015).

5 Vanderpump, M.P. (2011) The epidemiology of thyroid disease. British Medical Bulletin, 99, 39-51.

6 Tunbridge, W.M.G., Evered, D.C., Hall, R. et al. (1977) The spectrum of thyroid disease in the community: the Whickham survey. Clinical Endocrinology, 7, 481-493.

7 Grüters, A. \& Krude, H. (2007) Update on the management of congenital hypothyroidism. Hormone Research, 68(Suppl 5), $107-111$.

8 Association of Clinical Biochemistry, British Thyroid Association and British Thyroid Foundation. UK guidelines for the use of thyroid function tests (2006). Available from: www.britishthyroid-association.org. (Accessed: 17 May 2015)

9 Biondi, B. \& Cooper, D.S. (2008) The clinical significance of subclinical thyroid dysfunction. Endocrine Reviews, 29, 76131.

10 Vanderpump, M.P., Tunbridge, W.M., French, J.M. et al. (1995) The incidence of thyroid disorders in the community: a twentyyear follow-up of the Whickham Survey. Clinical Endocrinology (Oxford), 43, 55-68.

11 Wartofsky, L. \& Dickey, R.A. (2005) The evidence for a narrower thyrotropin reference range is compelling. Journal of Clinical Endocrinology and Metabolism, 90, 5483-5488.

12 Surks, M.I., Goswami, G. \& Daniels, G.H. (2005) The thyrotropin reference range should remain unchanged. Journal of Clinical Endocrinology and Metabolism, 90, 5489-5496.

13 Surks, M.I. \& Boucai, L. (2010) Age- and race-based serum thyrotropin reference limits. Journal of Clinical Endocrinology and Metabolism, 95, 496-502.

14 Canaris, G.J., Manowitz, N.R., Mayor, G. et al. (2000) The Colorado thyroid disease prevalence study. Archives of Internal Medicine, 160, 526-534.

15 Rugge, J.B., Bougatsos, C. \& Chou, R. (2015) Screening and treatment of thyroid dysfunction: an evidence review for the U.S. Preventive services task force. Annals of Internal Medicine, $162,35-45$.

16 Razvi, S., Shakoor, A., Vanderpump, M. et al. (2008) The influence of age on the relationship between subclinical hypothyroidism and ischemic heart disease: a metaanalysis. Journal of Clinical Endocrinology and Metabolism, 93, 2998-3007.

17 Rodondi, N., den Elzen, W.P., Bauer, D.C. et al. (2010) Subclinical hypothyroidism and the risk of coronary heart disease and mortality. JAMA 304, 1365-1374.

18 Cappola, A.R., Arnold, A.M., Wulczyn, K. et al. (2015) Thyroid function in the euthyroid range and adverse outcomes in older adults. Journal of Clinical Endocrinology and Metabolism, 100, 1088-1096.

19 De Groot, L., Abalovich, M., Alexander, E.K. et al. (2012) Management of thyroid dysfunction during pregnancy and postpartum: An Endocrine Society Clinical Practice Guideline. Journal of Clinical Endocrinology and Metabolism, 97, 2543-2565.

20 Mitchell, A.L., Hickey, B., Hickey, J.L. et al. (2009) Trends in thyroid hormone prescribing and consumption in the UK. BMC Public Health, 9, 132.

21 Biondi, B. \& Wartofsky, L. (2014) Treatment with thyroid hormone. Endocrine Reviews, 35, 433-512.

22 Saravanan, P., Chau, W.F., Roberts, N. et al. (2002) Psychological well-being in patients on 'adequate' doses of L-thyroxine: results of a large, controlled community-based questionnaire study. Clinical Endocrinology (Oxford), 57, 577-585.

23 Weetman, A.P. (2006) Whose thyroid hormone replacement is it anyway? Clinical Endocrinology (Oxford), 64, 231-233.

24 Burch, H.B., Burman, K.D., Cooper, D.S. et al. (2014) A survey of clinical practice patterns in the management of primary hypothyroidism. Journal of Clinical Endocrinology and Metabolism, 99, 2077-2085.

25 Royal College of Physicians. The diagnosis and management of primary hypothyroidism - revised statement (2011). Available from: https://www.rcplondon.ac.uk/resources/clinical-resources/ diagnosis-and-management-primary-hypothyroidism. (Accessed: 17 May 2015).

26 Wiersinga, W.M., Duntas, L., Fadeyev, V. et al. (2012) ETA Guidelines: the use of L-T4 + L-T3 in the treatment of hypothyroidism. European Thyroid Journal, 1, 55-71.

27 Jonklaas, J., Bianco, A.C., Bauer, A.J. et al. (2014) Guidelines for the treatment of hypothyroidism: prepared by the American Thyroid Association task force on thyroid hormone replacement. Thyroid, 24, 1670-1751.

28 Brenta, G., Vaisman, M., Sgarbi, J.A. et al. (2013) Clinical practice guidelines for the management of hypothyroidism. Arquivos Brasileiros de Endocrinologia e Metabologia, 57, 265-291.

29 Perros, P. (2012) European Thyroid Association guidelines on L-T4 + L-T3 combination for hypothyroidism: a weary step in the right direction. European Thyroid Journal, 1, 51-54.

30 Guyatt, G., Gutterman, D., Baumann, M.H. et al. (2006) Grading strength of recommendations and quality of evidence in clinical guidelines. Report from an American College of Chest Physicians Task Force. Chest, 129, 174-181.

31 Swiglo, B.A., Murad, M.H., Schunemann, H.J. et al. (2008) A case for clarity, consistency, and helpfulness: state-of-the-art clinical practice guidelines in endocrinology using the grading of recommendations, assessment, development, and evaluation system. Journal of Clinical Endocrinology and Metabolism, 93, 666-673. 